\title{
Clear Cell Ependymoma
}

National Cancer Institute

\section{Source}

National Cancer Institute. Clear Cell Ependymoma. NCI Thesaurus. Code C4714.

An ependymoma, often supratentorial in location, characterized by the presence of ependymal cells with a perinuclear halo. 